\section{EREM 72/4}

Journal of Environmental Research, Engineering and Management Vol. 72 / No. 4 / 2016 pp. 50-62
Phytoremediation Investigating Herbaceous Plants and Their Rhizosphere Microorganisms in the Mixture of Wood Sawdust of Used Sleepers and Soil Fertilised with Nitrogen
Received 2016/10
Accepted after revision 2016/12

\title{
Phytoremediation Investigating Herbaceous Plants and Their Rhizosphere Microorganisms in the Mixture of Wood Sawdust of Used Sleepers and Soil Fertilised with Nitrogen
}

Donatas Levišauskas, Tomas Tekorius, Valeras Kildišas

Department of Automation, Kaunas University of Technology, Studentu st. 50, LT-51368, Kaunas, Lithuania

Audrius Maruška, Nicola Tiso, Jurgita Mikašauskaitė, Tomas Drevinskas, Mantas Stankevičius, Rūta Mickienè, Violeta Bartkuvienè, Vilma Kaškonienè Olga Kornyšova

Faculty of Natural Sciences, Vytautas Magnus University, Vileikos st. 8, LT-40444, Kaunas Lithuania

Ona Ragažinskienè, Antanina Stankevičienè, Vilija Snieškienė

Botanical Garden of Vytautas Magnus University, Ž. E. Žilibero st. 6, LT-46324 Kaunas, Lithuania

Salvatore Fanali, Massimo Zacchini, Chiara Polcaro, Emanuella Galli, Enrica Donati National Research Council, Institute of Agro-Environmental and Forest Biology \& Institute of Chemical Methodologies, Area della Ricerca di Roma, via Salaria Km 29.300-00015, Monterotondo (Rome), Italy 
The studies were carried out in the period of 2013-2014 in an ex situ experiment developed during plant vegetation, cultivating 5 plant species in vegetative pots with a substrate contaminated with used sleepers and an uncontaminated substrate fertilised by nitrogenous fertilisers. The objective of the research was to analyse the morphological features of aboveground and underground parts of herbaceous plants and determine the dependence between the number of fungi and bacteria colonies in the rhizosphere of these plants and substrate contaminants and the impact of nitrogenous fertiliser concentration; with reference to that, to determine the feasibility of these plants for phytoremediation. A tolerant plant, i.e., Tagetes patula L. as a phytoremediator, which adapted to grow in the condition of a contaminated substrate fertilised by nitrogen and suitable for cultivating it in similar edaphic conditions, was used. An intolerant plant, i.e., Trifolium repens L. as a phytoindicator, is a perennial, herbaceous plant of Fabaceae Lindl. family, the rhizosphere of which contains the maximum number of fungi and bacteria colonies in the occurrence of the maximum concentration of nitrogenous fertilisers and contaminants. These bacteriological and mycological processes, as well as the excess of nitrogen, have a negative impact on the growth of aboveground and underground parts of Trifolium repens.

Keywords: phytoremediation, herbaceous plants, rhizosphere, microorganisms, substrate contamination, nitrogenous fertilisers.

\section{Introduction}

Nowadays, environmental pollution has become one of the greatest problems. Due to human economic activities, soil is polluted with heavy metals, oil products, pesticides, etc. From soil, pollutants access ecosystems and human food chain; they accumulate in the body and cause various diseases. Having designed the technology for cleaning toxic compounds from used wooden sleepers (US), it has contributed to the reduction of harmful impact on the environment and human health. This problem can be solved by developing innovative technologies, using herbaceous and ligneous plants, such as phytoremediation technology (Trapp, Karlson, 2001, Campos et al., 2008, Kathi and Khan, 2011). In the process of phytoremediation, model plants are selected, which would adapt to growing in the substrate contaminated with US. Plant roots substantially contribute to cleaning soil from contamination. Their secretions degrade toxic substances and protect soil from contamination. These plant species differ in quantitative and qualitative biochemical functioning and activity features, which affect plant growth under extreme conditions. According to Lithuanian and international scientific studies, in case of anthropogenic activity, soil and atmospheric pollution, phytoremediation, or phytorecultivation, is applied to various ecosystems. Model plants are selected with such physiological characteristics as suction power to absorb nutrients and chemical elements from soil and adaptation to extreme conditions, often by optimising them.
The wood of investigated used railway sleepers (US) was impregnated with creosote, shale oil and other bactericidal and fungicidal properties containing preservatives, which prevent the wood from decomposers. They contain phenolic compounds and polycyclic aromatic hydrocarbons (strong carcinogens). According to European Commission Directive 2001/90/EC (EURLEX-3200120090-LT), such waste cannot be directly used as fuel and compost or for other articles without additional treatment and neutralisation. Therefore, bioand phytoremediation technologies are applied, which are based on the ability of microorganisms and plants to degrade phenols and even polycyclic aromatic hydrocarbons, possessing strong carcinogenic properties. In Lithuania, phytoremediation studies on the substrate containing used wooden sleepers were carried out for the first time.

Currently, there is not enough information about microorganisms isolated directly from the polluted environment, their diversity or ability to degrade the creosote. Therefore, not so many species of fungi are used for bioremediation. It is necessary to identify the local species of fungi capable of degrading creosote and apply these fungi for bioremediation (Kim et al., 2010).

Competition for nutrients between plants and microorganisms may have impeded the microbial degradation of PAHs in the rhizosphere (Smith et al., 2008, Sun et al., 2010). 
The aim of the research was to analyse the morphological features of aboveground and underground parts of herbaceous plants and determine the dependence between the number of fungi and bacteria colonies in the rhizosphere of these plants and substrate contaminants and the impact of the concentration of a nitrogenous fertiliser; on that basis, to assess the feasibility of these plants for phytoremediation

\section{Research methods}

The research object is herbaceous plants and their rhizosphere microorganisms (fungi and bacteria) in an ex situ experiment in vegetative pots with a contaminated substrate.

\section{Substrate variations during the experiment}

The primary substrate was prepared from the upper type of peat and cattle manure (1:4). After crushing and sieving, $1 \mathrm{~kg} \mathrm{~m}^{-3}$ of NPK 12-10-16 mineral fertiliser with microelements was inserted into the composted ground. Substrate acidity ranged from 5.5 to 7.0 , and the humidity was up to $70 \%$. Based on this primary substrate $\left(\mathrm{C}_{0}\right)$, the mixtures were prepared, in which plants were sowed or planted. Three variations of clean Scots pine (Pinus sylvestris L.) sawdust $\left(\mathrm{C}_{12,5}, \mathrm{C}_{25}\right.$, ir $\left.\mathrm{C}_{37,5}\right)$ and the same variations of creosote-treated sleepers made from Scots pine sawdust were placed in the primary substrate (Table 1).
Having designed the experiment ex situ, the research was carried out in the period of 2013-2014, during plant vegetation, at Kaunas Botanical Garden of Vytautas Magnus University (VMU). Five plant species were cultivated in vegetative pots with a contaminated US and an uncontaminated substrate at the Instrumental Chemistry Analysis Laboratory of VMU Faculty of Natural Sciences and Open Access Centre. The processing of the data was performed at the Department of Automation of Kaunas University of Technology.

The studies of cultivation and development of plants, morphological features of their aboveground and underground parts and phytomass implementing the methods of outdoor experiments and introduction research (Stancevičius, Arvasas, 1981, Ragažinskienè et al., 2008).

\section{Investigation methods of the number of microorganism colonies}

For mycological examination, the substrate samples were taken from the rhizosphere of 5 plant species: Tagetes patula, Portulaca oleracea, Perilla frutescens, Poa annua and Lupinus luteus. The reference samples were taken from the pure substrate $\left(C_{0}\right)$, the substrate with pure Pinus sylvestris chips mixed at appropriate ratios $\left(\mathrm{C}_{12.5}, \mathrm{C}_{25}, \mathrm{C}_{37.5}\right)$ and the corresponding substrate pre-mixed with chips of used wooden railway sleepers $\left(\mathrm{CS}_{12.5}, \mathrm{CS}_{25}, \mathrm{CS}_{37.5}\right)$. Keeping aseptic sampling conditions, the substrate samples were taken 3 times with 3 repetitions of the substrate prepared for planting
Table 1

Conditions of the ex situ experiment in vegetative pots. 2013, Kaunas Botanical Garden of Vytautas Magnus University.

\begin{tabular}{|c|c|c|}
\hline $\begin{array}{c}\text { Conventional } \\
\text { notation }\end{array}$ & Experiment variants & Plants \\
\hline 1 & 2 & 3 \\
\hline $\mathrm{C}_{0}$ & Primary substrate $100(\%)$ & \multirow{7}{*}{$\begin{array}{l}\text { The following plant } \\
\text { species were repeatedly } \\
\text { planted in vegetative } \\
\text { pots with an appropriate } \\
\text { substrate for } 5 \text { times: } \\
\text { Tagetes patula L., } \\
\text { Portulaca oleracea L., } \\
\text { Perilla frutescens (L.) } \\
\text { Britton., Poa annua L. } \\
\text { and Lupinus luteus L. }\end{array}$} \\
\hline $\mathrm{C}_{12,5}$ & Primary substrate $87.5 \%+$ Pinus sylvestris sawdust $12.5 \%$ & \\
\hline $\mathrm{C}_{25}$ & Primary substrate $75 \%+$ Pinus sylvestris sawdust 25\% & \\
\hline $\mathrm{C}_{37,5}$ & Primary substrate $62.5 \%$ + Pinus sylvestris sawdust $37.5 \%$ & \\
\hline $\mathrm{CS}_{12,5}$ & Primary substrate $87.5 \%$ + sleepers sawdust $12.5 \%$ & \\
\hline $\mathrm{CS}_{25}$ & Primary substrate75\% + sleepers sawdust $25 \%$ & \\
\hline $\mathrm{CS}_{37,5}$ & Primary substrate $62.5 \%$ + sleepers sawdust $37.5 \%$ & \\
\hline
\end{tabular}


the plants (29.06.2013), in the middle stage of vegetation (02.08.2013) and at the end of vegetation of plants (17.09.2013), and, in 2014, out of the rhizosphere of 2 plant species, namely, Tagetes patula and Trifolium repens.

Collected on the same day, the samples were prepared for microbiota (fungi and bacteria) isolation and identification. Substrate microbiota was isolated using a biological method of isolation of pure cultures. Soil samples were dried, homogenised, sieved with a $2 \mathrm{~mm}$ pore size test sieve and conserved at $4^{\circ} \mathrm{C}$. The substrate $(10 \mathrm{~g})$ was transferred to a $100 \mathrm{~mL}$ flask with distilled water and shaken for $20 \mathrm{~min}$. Serial dilutions of up to 1:1,000 were carried out: $1 \mathrm{~mL}$ of the suspension was pipetted and poured into a vial with $10 \mathrm{~mL}$ of distilled water, of which again $1 \mathrm{~mL}$ of the suspension was pipetted and transferred into a vial with $10 \mathrm{~mL}$ of distilled water. The suspension $(1 \mathrm{~mL})$ from the latter vial was taken and transferred into a Petri dish and poured into solution, where $2 \%$ malt extract agar (MEA) medium cooled to $40^{\circ} \mathrm{C}$ (Parkinson et al., 1971). Nutrient agar (NA) was produced using the manufacturer's (National Public Health Surveillance Laboratory, Lithuania) specifications for the product. Three replicates were used for each experiment. Crops were incubated in a thermostatic chamber at $26 \pm 2^{\circ} \mathrm{C}$ temperature. Counting was performed after 5 days.

The fungi and bacteria origins in $1 \mathrm{~g}$ of air-dry substrate (colony forming units, CFU) were calculated using the following formula:

$$
a=\frac{b \cdot c \cdot d}{e}
$$

where

$b$ - average number of colonies per plate, $c$ - dilution from which fungi and bacteria sowing was made (1:1000), $d$ - amount of suspension inoculated into the dish $(1 \mathrm{~mL}), e$ - air-dry weight of the substrate taken for analysis (1 g) (Zviagincev, 1991).

\section{Processing of experimental data}

For modelling and graphical presentation of the experimental data, the mean values of the results of parallel or repeated experiments were used. In the investigations, the response surface methodology (RSM) (Myers et al., 2002, Montgomery, 2001, Makarevičienè et al., 2013) was applied, which covers the design of factorial experiments, development of response surface models and response surface analysis.

The RSM was applied to investigate an impact of pollutant and fertiliser concentrations on plant biometrical parameters and numbers of bacteria and fungi colonies in the rhizosphere of the plants.

\section{Experimental investigations and results}

\section{Preliminary phytoremediation experiment}

A preliminary phytoremediation experiment ex situ was performed in 2013. The PAH tolerance of 5 annual plant species - Tagetes patula, Poa annua, Portulaca oleracea, Perilla frutescens, and Lupinus luteus - which grow in the mixture of contaminated and uncontaminated US sawdust of Pinus sylvestris wood and soil (Table 1) was investigated. The preliminary experiments showed that the phytoremediator Tagetes patula was tolerant to the contamination of soil.

This experiment demonstrated that the contamination did not have any negative impact on the growth of the plant aboveground part (Figure 1, 2). The major role of soil cleaning is performed by the biomass of the plant underground part, the significance of which statistically is higher in the contaminated substrate, rather than in the tested variants using clean sawdust of Pinus sylvestris (Figure 3, 4).

In order to investigate an impact of pollutant and fertiliser concentrations on the biometrical parameters of Tagetes patula and Trifolium pratense, and the numbers of bacteria and fungi colonies in the rhizosphere, the factorial experiments were realised.

The experimental design for the factors (pollutant and fertiliser concentrations) in coded and real units along with the experimental results are shown in Table 2 (for Tagetes patula) and Table 3 (for Trifolium pratense). 
Fig. 1

Dependence of the dry mass of the aboveground part of Tagetes patula L. on percentage concentration of wood cuttings: (a) - control, (b) - substrate polluted with used sleeper cuttings

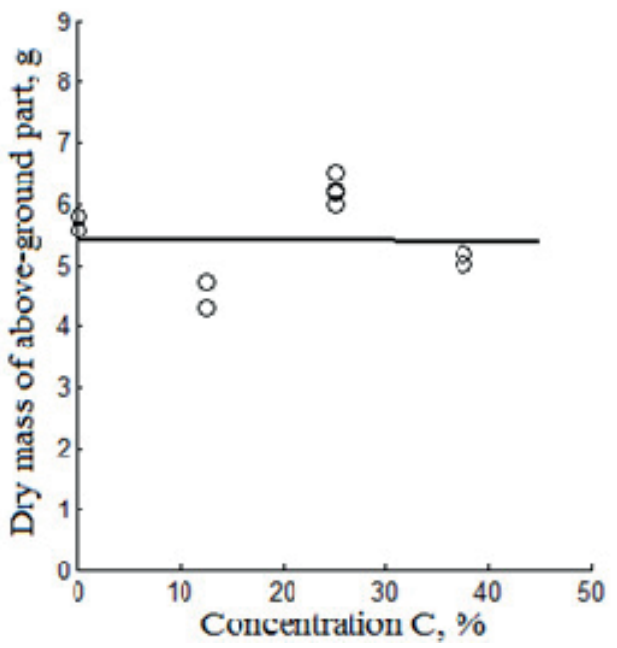

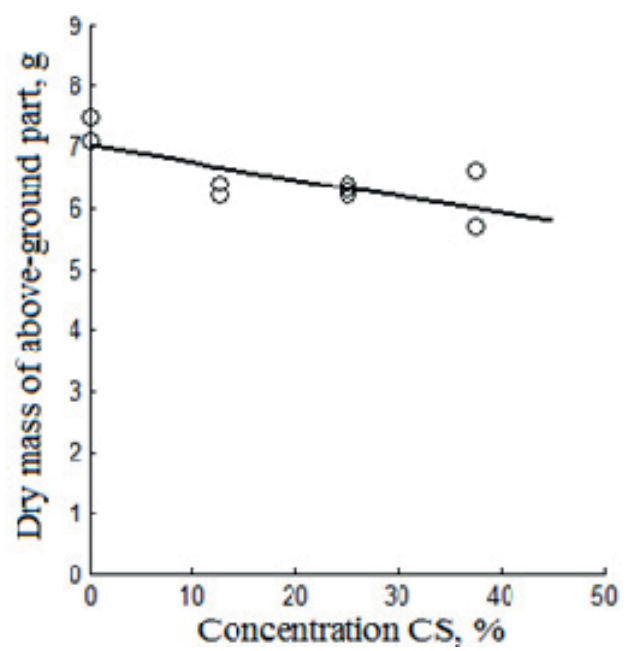

b

Fig. 2

Comparison of the dry mass of the aboveground part of Tagetes patula L. at various percentages of wood cuttings:

(a) - control (gray columns), (b) substrate polluted with used sleeper cuttings (black columns)

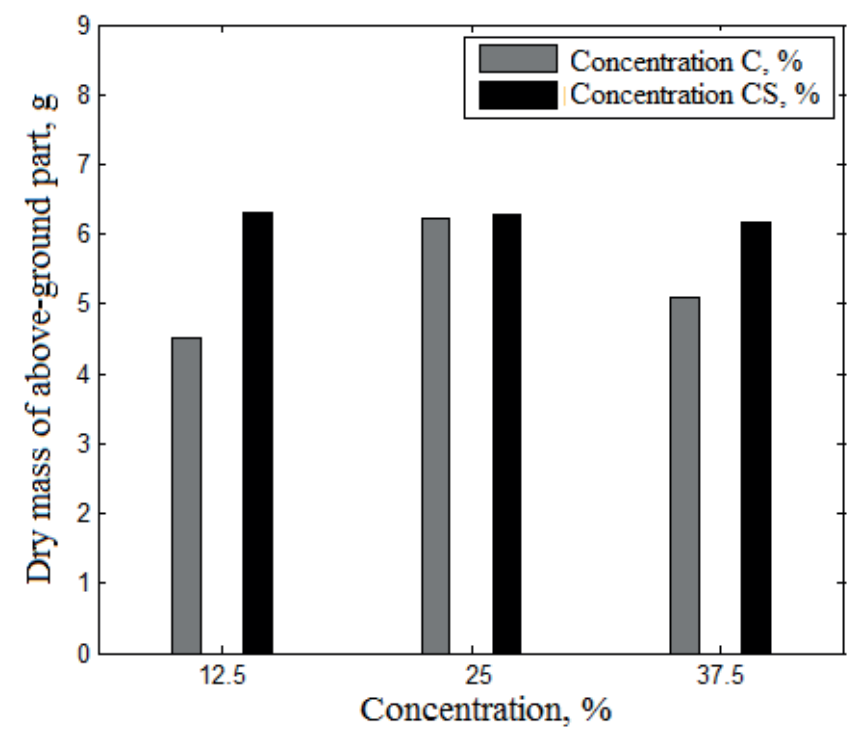


Fig. 3

Dependence of the green mass of the underground part of Tagetes patula $\mathrm{L}$. on percentage concentration of wood cuttings: (a) - control, (b) - substrate polluted with used sleeper cuttings

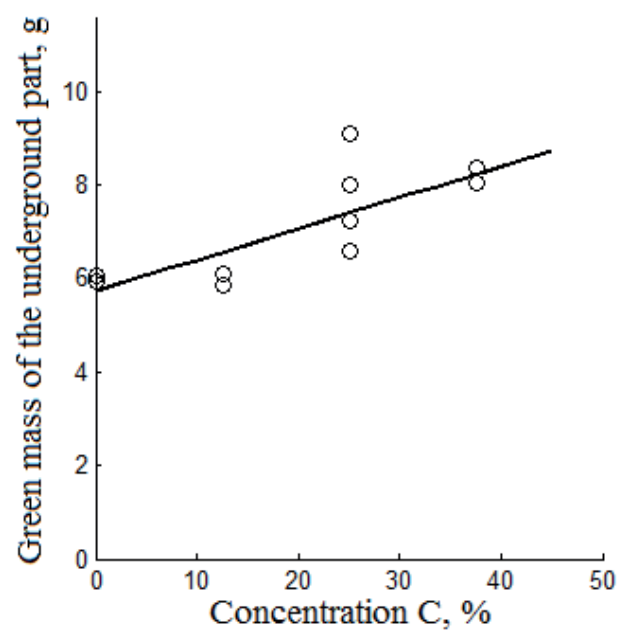

a

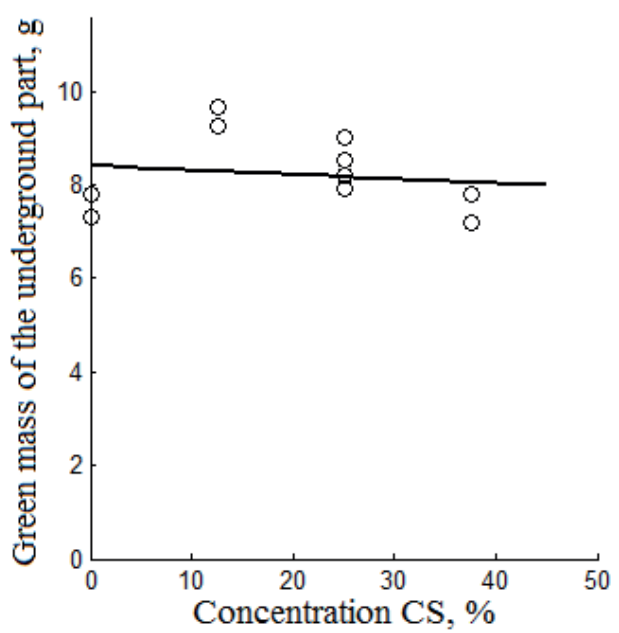

b

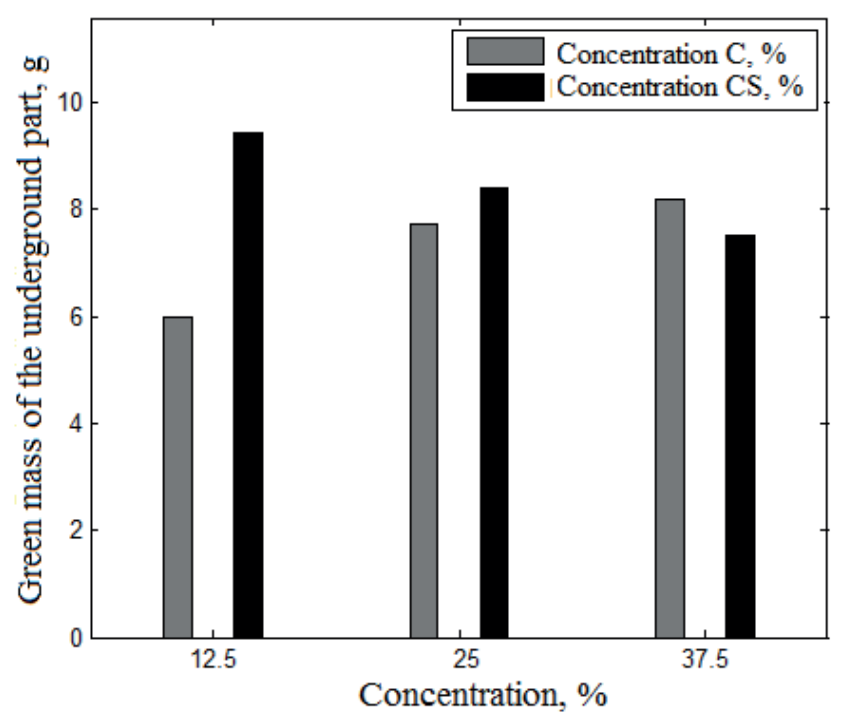

Fig. 4

Comparison of the green mass of the underground part of Tagetes patula $\mathrm{L}$. at various percentages of wood cuttings:

(a) - control (gray columns), (b) substrate polluted with used sleeper cuttings (black columns) 


\section{Table 2}

Experimental design matrix along with the experimental results for Tagetespatula $\mathrm{L}$.

\begin{tabular}{|c|c|c|c|c|c|c|c|c|}
\hline \multirow{3}{*}{$\begin{array}{l}\text { Exp. } \\
\text { No. }\end{array}$} & \multicolumn{4}{|c|}{ Experimental conditions (factor values) } & \multirow{3}{*}{$\begin{array}{c}\text { Height of the } \\
\text { aboveground } \\
\text { part, }[\mathrm{cm}]\end{array}$} & \multirow{3}{*}{$\begin{array}{l}\text { Green mass of } \\
\text { the under- } \\
\text { ground part [g] }\end{array}$} & \multirow{3}{*}{$\begin{array}{l}\text { Number } \\
\text { of bacteria } \\
\text { colonies }\end{array}$} & \multirow{3}{*}{$\begin{array}{l}\text { Number of } \\
\text { fungi colonies }\end{array}$} \\
\hline & \multicolumn{2}{|c|}{ Pollutant concentration, [\%] } & \multicolumn{2}{|c|}{$\mathrm{NH}_{4} \mathrm{NO}_{3}$ concentration $\left[\mathrm{mg} \mathrm{cm}^{-3}\right]$} & & & & \\
\hline & code & real & code & real & & & & \\
\hline 1 & 2 & 3 & 4 & 5 & 6 & 7 & 8 & 9 \\
\hline 1 & 1 & 5 & 1 & 4.62 & 31.0 & 12.5 & 99 & 10 \\
\hline 2 & -1 & 0 & 1 & 4.62 & 30.3 & 14.1 & 1029 & 9.8 \\
\hline 3 & 1 & 5 & -1 & 0 & 19.4 & 1.60 & 3116 & 13 \\
\hline 4 & -1 & 0 & -1 & 0 & 25.6 & 4.11 & 586 & 15.8 \\
\hline 5 & 1 & 5 & 0 & 2.31 & 28.3 & 11.1 & 250 & 9 \\
\hline 6 & -1 & 0 & 0 & 2.31 & 30.5 & 6.68 & 41 & 10 \\
\hline 7 & 0 & 2.5 & 1 & 4.62 & 34.3 & 10.0 & 2750 & 9.5 \\
\hline 8 & 0 & 2.5 & -1 & 0 & 18.6 & 2.08 & 4475 & 11.5 \\
\hline 9 & 0 & 2.5 & 0 & 2.31 & 29.1 & 7.55 & 2250 & 10.8 \\
\hline
\end{tabular}

\section{Table 3}

Experimental design matrix along with the experimental results for Trifolium pratense L.

\begin{tabular}{|c|c|c|c|c|c|c|c|}
\hline \multirow{3}{*}{$\begin{array}{l}\text { Exp. } \\
\text { No. }\end{array}$} & \multicolumn{4}{|c|}{ Experimental conditions (factor values) } & \multirow{3}{*}{$\begin{array}{c}\text { Plane area of the } \\
\text { aboveground part, } \\
{\left[\mathrm{cm}^{2}\right]}\end{array}$} & \multirow{3}{*}{$\begin{array}{c}\text { Green mass of } \\
\text { the underground } \\
\text { part [g] }\end{array}$} & \multirow{3}{*}{$\begin{array}{c}\text { Number of bacteria } \\
\text { colonies }\end{array}$} \\
\hline & \multicolumn{2}{|c|}{ Pollutant concentration, [\%] } & \multicolumn{2}{|c|}{$\mathrm{NH}_{4} \mathrm{NO}_{3}$ concentration $\left[\mathrm{mg} \mathrm{cm}^{-3}\right.$ ] } & & & \\
\hline & code & real & code & real & & & \\
\hline 1 & 2 & 3 & 4 & 5 & 6 & 7 & 8 \\
\hline 1 & 1 & 5 & 1 & 4.62 & 241 & 4.2 & 1970 \\
\hline 2 & -1 & 0 & 1 & 4.62 & 1347 & 11.1 & 1430 \\
\hline 3 & 1 & 5 & -1 & 0 & 477 & 3.58 & 1450 \\
\hline 4 & -1 & 0 & -1 & 0 & 808 & 3.98 & 582 \\
\hline 5 & 1 & 5 & 0 & 2.31 & 82 & 2.28 & 1000 \\
\hline 6 & -1 & 0 & 0 & 2.31 & 1576 & 5.62 & 698 \\
\hline 7 & 0 & 2.5 & 1 & 4.62 & 873 & 3.68 & 940 \\
\hline 8 & 0 & 2.5 & -1 & 0 & 626 & 3.02 & 462 \\
\hline 9 & 0 & 2.5 & 0 & 2.31 & 220 & 3.95 & 505 \\
\hline
\end{tabular}

The impact of pollutant and fertiliser concentrations on morphological features of the aboveground and underground parts of investigated plants

From the data in Table 2 and Table 3, the response surface models were developed, which describe the depen- dence of the biometrical parameters of the investigated plants and the numbers of bacteria and fungi colonies on pollutant and fertiliser concentrations. The response surfaces were modelled using $2^{\text {nd }}$ order polynomial models (Myers et al., 2002, Makarevičienè et al., 2013). The identified models are presented in Tables 4, 5 . 


\section{Table 4}

Response surface models for prediction of biometrical parameters of Tagetes patula and respective numbers of bacteria and fungi colonies ( $Y$ predicted response, $x_{1}$ - pollutant concentration, $x_{2}-\mathrm{NH}_{4} \mathrm{NO}_{3} \mathrm{NH}_{4} \mathrm{NO}_{3}$ concentration; model parameters are given for the coded values of factors)

\begin{tabular}{l|c}
\multicolumn{1}{c|}{ Response parameter } & \multicolumn{1}{c}{ Response surface model } \\
\hline \multicolumn{1}{c|}{1} & \\
\hline Height of the aboveground part & $Y=29.1-1.28 x_{1}+5.33 x_{2}+0.183 x_{1}^{2}-2.76 x_{2}^{2}+1.72 x_{1} x_{2}$ \\
\hline Green mass of the underground part & $Y=7.24+0.0516 x_{1}+4.80 x_{2}+1.80 x_{1}^{2}-1.04 x_{2}^{2}+0.227 x_{1} x_{2}$ \\
\hline Number of bacteria colonies & $Y=2383+301 x_{1}-716 x_{2}-2304 x_{1}^{2}+1162 x_{2}^{2}-865 x_{1} x_{2}$ \\
\hline Number of fungi colonies & $Y=9.48-0.600 x_{1}-1.83 x_{2}+0.666 x_{1}^{2}+1.66 x_{2}^{2}+0.750 x_{1} x_{2}$ \\
\hline
\end{tabular}

\section{Table 5}

Response surface models for prediction of biometrical parameters of Trifolium pratense $L$. and respective numbers of bacteria and fungi colonies

\begin{tabular}{l|c}
\hline \multicolumn{1}{c|}{ Response parameter } & Response surface model \\
\hline 1 & \\
\hline Plane area of the aboveground part & $Y=504-488 x_{1}+91.6 x_{2}+182 x_{1}^{2}+102 x_{2}^{2}-193 x_{1} x_{2}$ \\
\hline Green mass of the underground part & $Y=2.89-1.77 x_{1}+1.40 x_{2}+1.57 x_{1}^{2}+0.976 x_{2}^{2}-1.62 x_{1} x_{2}$ \\
\hline Number of bacteria colonies & $Y=365+284 x_{1}+308 x_{2}+553 x_{1}^{2}+405 x_{2}^{2}-82.7 x_{1} x_{2}$ \\
\hline
\end{tabular}

The response surfaces for predicting dependence of the biometrical parameters of Tagetes (height of the aboveground part and green mass of the underground part) on pollutant and fertiliser concentrations at the end of the vegetation cycle are presented in Figures 5 a and b. The fertiliser has a positive impact, and the pollutant concentration does not have a significant negative impact on the height of the aboveground part. Favourable conditions for the growth of Tagetes along the entire range of pollutant concentration variations are predicted at the maximum concentration of the fertiliser $\left(4.62 \mathrm{mg} \mathrm{cm}^{-3}\right.$ ).

The green mass of the underground part of Tagetes is correlated with the height of the aboveground part, and its dependence on pollutant and fertiliser concentrations is similar to that of the height of the aboveground part. The maximum values of the height of the aboveground part and the green mass of the underground part are gained at the maximum investigated concentrations of the pollutant and the fertiliser.

The response surfaces of the biometrical parameters of Trifolium pratense (plane area of the aboveground part and green mass of the underground part) at the end of the vegetation cycle are presented in Figures $6 a$ and $b$. Favourable conditions for the growth of $T$. pratense are observed in the soil without pollutants at the maximum concentration of the fertiliser $\left(4.62 \mathrm{mg} \mathrm{cm}^{-3}\right)$. The plant is sensitive to pollutants: the plane area of the aboveground part significantly decreases with increasing pollutant concentration.

The green mass of the underground part also apparently depends on pollutant concentration: the green mass decreases with increasing pollutant concentration. The maximum green mass of the underground part is observed in the soil without pollutants at the maximum concentration of the fertiliser. 
Fig. 5

Simulated dependences of the height of the aboveground part $(\mathrm{cm})$ and the green mass of the underground part $(\mathrm{g})$ of Tagetes patula (response surfaces (a) and (b), respectively) on the concentrations of the pollutant and the fertiliser. The points indicate the maximum predicted values

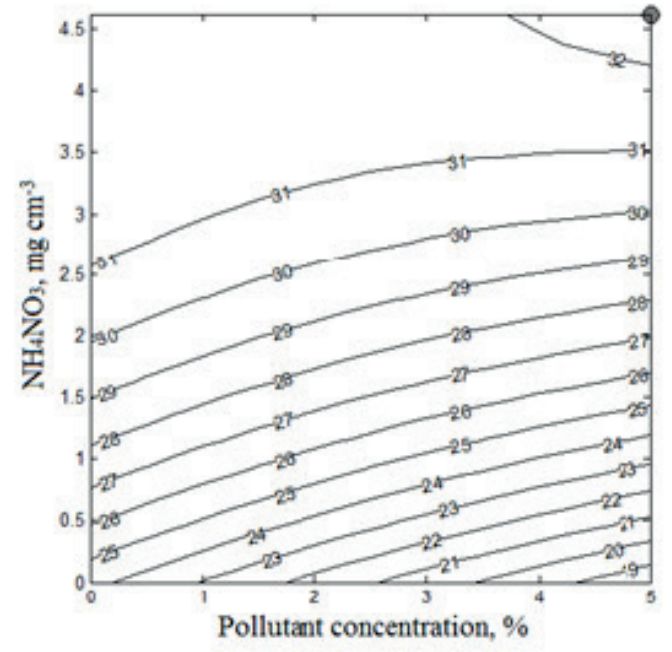

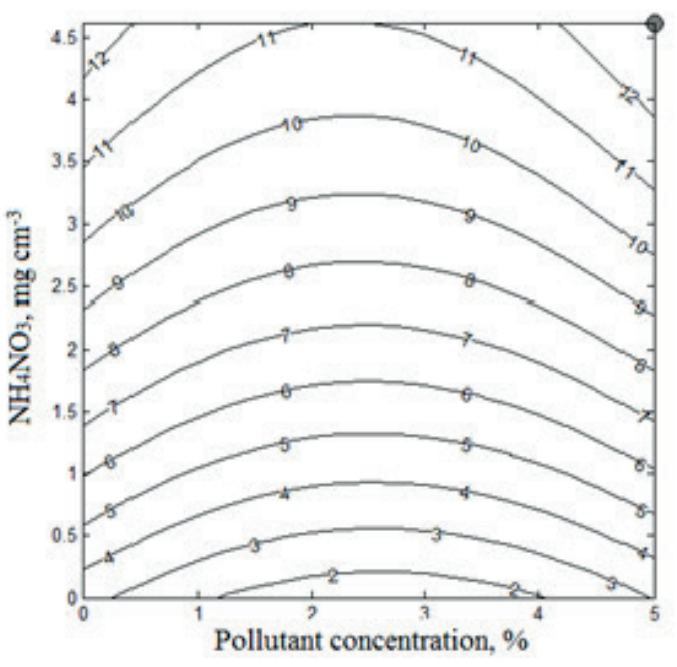

b

Fig. 6

Simulated dependences of the plane area of the aboveground part $(\mathrm{cm})$ and the green mass of the underground part $(\mathrm{g})$ of Trifolium pratense $\mathrm{L}$. (response surfaces (a) and (b), respectively) on the concentrations of the pollutant and the fertiliser. The points indicate the maximum predicted values

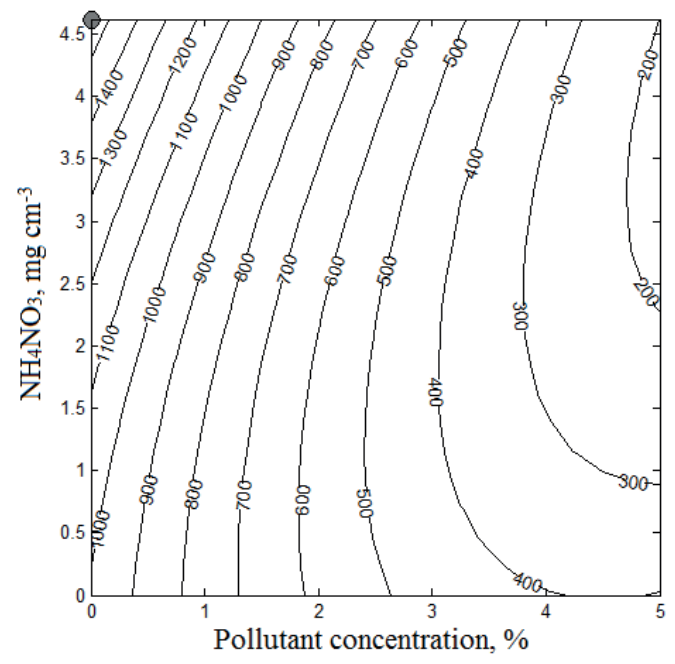

a

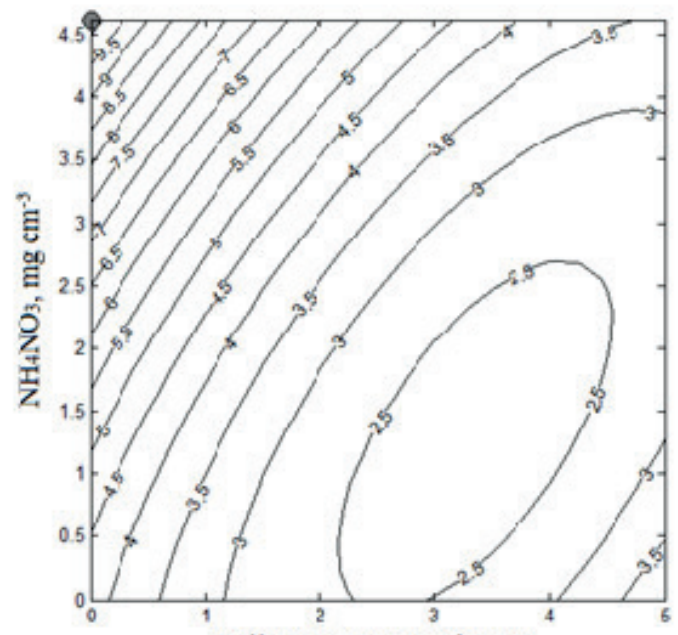

Pollutant concentration, $\%$ 


\section{The impact of pollutant and fertiliser concentrations on the number of bacteria and fungi colonies in rhizospheres of the investigated plants}

The response surfaces of the numbers of bacteria and fungi colonies in the rhizosphere of Tagetes patula at the end of the vegetation cycle are presented in Figures $7 \mathrm{a}$ and $\mathrm{b}$.

The biggest number of bacteria colonies in the rhizosphere of Tagetes is observed at the end of the vegetation period. The maximum number of colonies is predicted in the soil without the fertiliser at the initial concentration of pollutants $3 \mathrm{mg} \mathrm{cm}$. The biggest number of fungi colonies is also observed at the end of the vegetation period, and the biggest number is predicted in the soil without the pollutant and the fertiliser.

In Figure 8, the response surface is presented, which shows dependence of the number of bacteria colonies on pollutant and fertiliser concentrations in the rhizosphere of Trifolium pratense in the middle of the vege- tation period. The relationship between the number of fungi colonies and pollutant and fertiliser concentrations was not detected.

In the rhizosphere of $T$. pratense, the maximum number of bacteria colonies was observed in the middle of the vegetation period. The maximum number is predicted in the soil with the maximum concentrations of the pollutant (5\%) and the fertiliser $\left(4.62 \mathrm{mg} \mathrm{cm}^{-3}\right)$. The biggest numbers of fungi colonies in the rhizosphere of Trifolium were observed at the end of the vegetation period; however, the experimental data did not show a noticeable dependence of the number of colonies on pollutant and fertiliser concentrations.

The analysis of the numbers of bacteria and fungi colonies in the rhizosphere of Tagetes patula and Trifolium pratense demonstrates that the biggest number of bacteria $(\sim 400)$ is predicted in the Tagetes rhizosphere at lower concentrations of the pollutant and the fertiliser. In the substrates with bigger concentrations of the pollutant, the bigger numbers of bacteria

Fig. 7

Simulated dependences of the numbers of bacteria and fungi colonies in the rhizosphere of Tagetes patula $\mathrm{L}$. (response surfaces (a) and (b), respectively) on the concentrations of the pollutant and the fertiliser. The points indicate the maximum predicted values

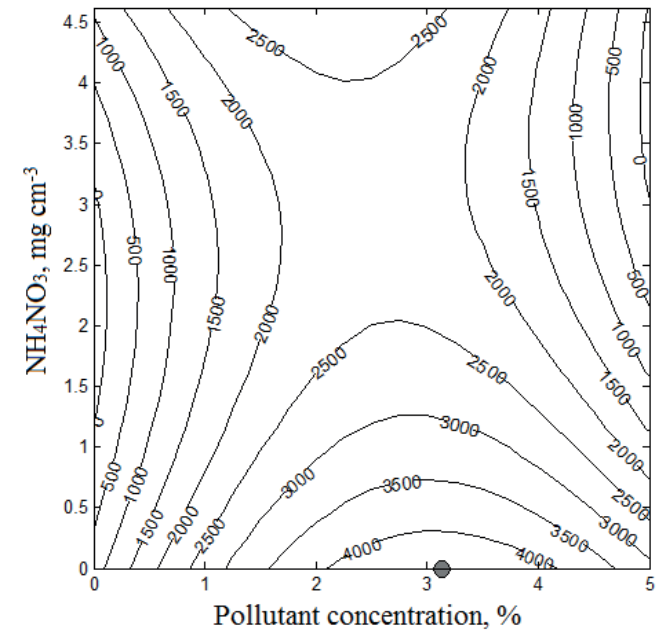

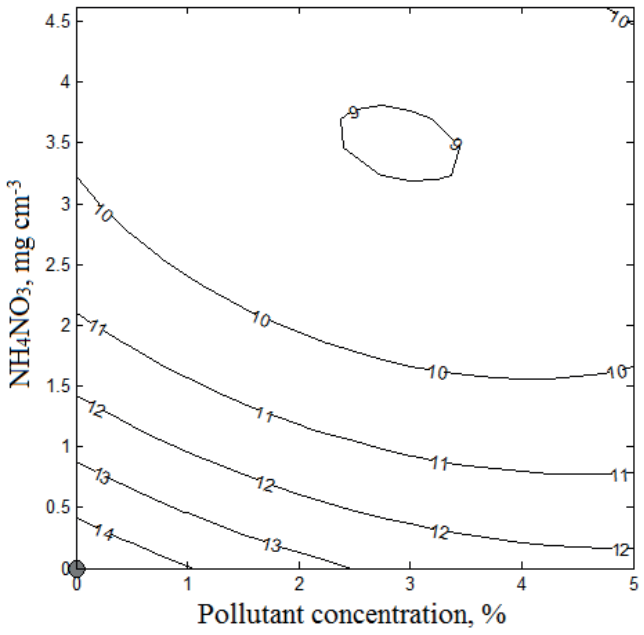

b 
Fig. 8

Simulated dependence (response surface) of the number of bacteria colonies in the rhizosphere of Trifolium on the concentrations of the pollutant and the fertiliser. The point indicates the maximum predicted value

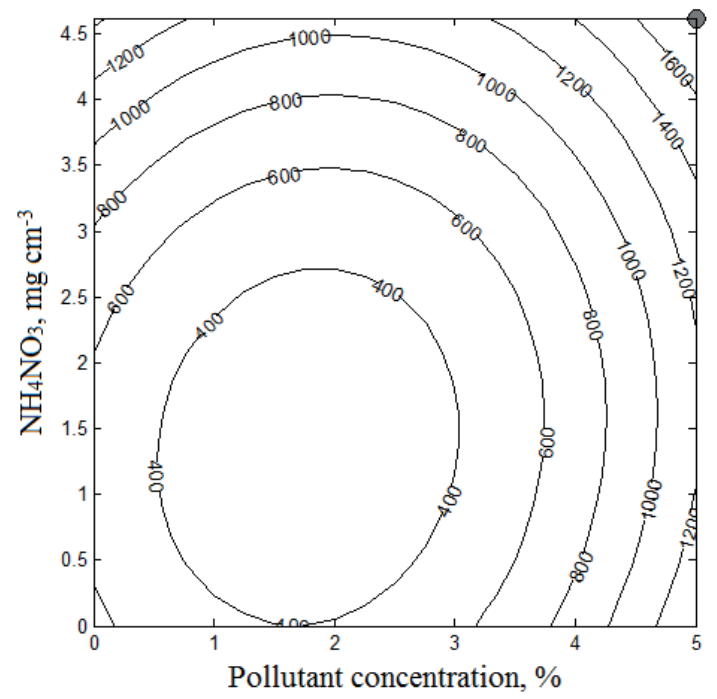

colonies are predicted in the rhizosphere of Trifolium. The maximum numbers of fungi colonies in the rhizospheres of Tagetes and Trifolium are similar (20-22). In the rhizosphere of Tagetes, the maximum number of colonies is predicted in the substrate without the pollutant and the fertiliser. Meanwhile in the rhizosphere of Trifolium, the maximum number of fungi colonies is predicted at the maximum initial concentrations of the pollutant (5\%) and the fertiliser $\left(4.62 \mathrm{mg} \mathrm{cm}^{-3}\right)$.

\section{Conclusions}

In the period of 2013-2014, the phytoremediation experiment was conducted ex situ in the contaminated substrate (the mixture of wood sawdust of used sleepers (US) of scots pine (Pinus sylvestris L.) and humous black earth soil) placed in vegetative pots and fertilised by nitrogenous fertilisers.

A tolerant plant, i.e., a phytoremediator Tagetes patula L., a herbaceous, decorative, medicinal, annual Asteraceae Dumort family plant, which adapted to grow in the conditions of a contaminated substrate fertilised by nitrogenous fertilisers, is potentially suitable and recommended for the cultivation under similar ecologic conditions. The height of the plant aboveground part and biomass of the plant underground part reach the highest point when there is the maximum concentration of substrate contaminants and fertilisers, which has a positive impact on the growth of the aboveground part and underground parts of the plant.

An intolerant plant, i.e., a phytoindicator Trifolium repens L., a perennial, herbaceous Fabaceae Lindl. family plant, in the rhizosphere of which contamination is high, demonstrates intensive bacteriological and mycological processes, having a negative impact on the growth of the aboveground and underground parts of Trifolium repens. Thus, it is not advisable to cultivate this plant in the condition of a contaminated and fertilised substrate. The highest number of bacteria colonies ( 4400) is foreseen in the rhizosphere of Tagetes patula, when the concentration of contaminants and fertilisers is lower. The higher number of bacteria colonies in the rhizosphere of Trifolium repens is predicted in the substrate with a higher contamination concentration.

The maximum numbers of fungi colonies in the rhizosphere of Tagetes patula and Trifolium repens are similar (20-22). In the rhizosphere of Tagetes patula, the maximum number of these colonies is predicted in the substrate without any fertilisers and contaminants, 
while in the rhizosphere of Trifolium repens, the maximum number of fungi colonies is foreseen in the occurrence of the maximum initial concentrations of contaminants (5\%) and fertilisers (4.62\%), which means that in the rhizosphere of this plant, in the occurrence of high rhizosphere contamination, intensive bacteriological and mycological processes take place.

\section{References}

Campos V. M., Merino I., Casado R., Pacios L. F. and Gómez L. (2008) Review. Phytoremediation of organic pollutants. Spanish Journal of Agricultural Research, 6 (Special issue), 38-47. https://doi.org/10.5424/sjar/200806S1-372

European Commision Directive 13/26 t. European Communities Official Directive L 283/41. Commission Directive 2001/90 / EC. (2001) October 26 th., 454-456 p.

Kathi S. and Khan A. B. (2011) Phytoremediation approaches to PAH contaminate soil. Journal of Science and Technology, 4(1): 56-63.

Kim M-J., Lee H., Coi Y-S., im G-H., Huh N-Y, Lee S., Lim Y. W., Lee S-S., Kim J-J. (2010). Diversity of fungi in creosote-treated crosstie wastes and their resistance to polycyclic aromatic hydrocarbons. Antonie van Leeuwenhoe, 97: 377-387. https://doi.org/10.1007/s10482-010-9416-6

Makareviciene, V., Skorupskaite, V., Levisauskas, D., Andruleviciute, V., Kazancev, K. (2013). The optimization of biodysel fuel production from microalgae oil using response surface methodology. International Journal of Green Energy. November: 527-541.

Montgomery, D. C. (2001). Design and Analysis of Experiments. John Wiley\&Sons.

Myers, R. H., Montgomery, D. C. (2002). Response Surface Methodology. Process and Product Optimization

\section{Acknowledgements}

This research was financed from EFSA, grant No. VP13.1-ŠMM-10-V-02-010 (BIOREM). Technical assistance from E. Šeinauskiene, K. Barčauskaite and M. Kazlauskas preparing the substrate and wooden sleeper chips is acknowledged.

Using Designed Experiments. John Wiley \& Sons.704. Parkinson, D., Gray, T.R.G., Williams, S.T. (1971) Ecology of Soil Microorganisms, p.116, Blackwell, Oxford.

Ragažinskienè O., Lapinskienè N., Kornyšova O., Maruška A. (2008) Application introduction methods for determine medicinal plants biological characteristic . Journal of Young Scientists 3(19): 113-117.

Stancevičius A. and Arvasas J. (1981) Methodology of measurement of field trial data, p. 68, Kaunas, Lž̄̄A.

Smith K. E., Schwab A. P., Banks M. K. (2008) Dissipation of PAHs in saturated, dredged sediments: a field trial. Chemosphere 72: 1614-1619. https://doi.org/10.1016/j. chemosphere.2008.03.020

Sun T. R., Cang L., Wang Q. Y., Zhou D.M., Cheng J.M., Xu H. (2010) Roles of abiotic losses, microbes, plant roots, and root exudates on phytoremediation of PAHs in a barren soil. Journal Hazard Mater. 176: 919-925. https://doi.org/10.1016/j. jhazmat.2009.11.124

Trapp S. and Karlson U. (2001) Aspects of Phytoremediation of Organic Pollutants. Journal Soils \& Sediments 1- review article. https://doi.org/10.1007/bf02986468

Zviagincev, D. G. (1991) Methods of soil microbiology and biochemistry, 304 p., Moskva, Nauka(in Russian). 


\section{Fitoremedijacija tiriant žolinius augalus ir jų rizosferos mikroorganizmus subostate - naudotų pabégių medienos pjuvenų mišinyje su dirvožemiu tręšiamu azotu}

\section{Donatas Levišauskas, Tomas Tekorius, Valeras Kildišas}

Automatikos katedra, Kauno technologijos universitetas, Kaunas, Lietuva

Audrius Maruška, Nicola Tiso, Jurgita Mikašauskaitè, Tomas Drevinskas, Mantas Stankevičius, Rūta Mickienė, Violeta Bartkuvienė, Vilma Kaškonienè, Olga Kornyšova

Gamtos mokslų fakuiltetas, Aplinkotyros katedra, Vytauto Didžiojo Universitetas, Kaunas, Lietuva

\section{Ona Ragažinskienè, Antanina Stankevičienè, Vilija Snieškienè}

Vytauto Didžiojo universiteto Botanikos sodas, Kaunas, Lietuva

\section{Salvatore Fanali, Massimo Zacchini, Chiara Polcaro, Emanuella Galli, Enrica Donati}

Nacionalinė mokslo taryba, Agro-aplinkos ir miškų institutas \& Cheminės metodologijos institutas, Roma, Italija

Tyrimai atlikti 2013-2014 metais augalu vegetacijos metu sukurtame bandyme ex situ, auginant penkiu rūšių augalus vegetaciniuose induose su užterštu naudotų medinių pabėgių pjuvenomis ir neužterštu substratu tręšiamu azoto trąšomis. Tyrimų tikslas - ištirti žoliniu augalų antžeminès ir požeminès daliu morfologiniu savybių ir šių augalu rizosferoje grybų bei bakteriju koloniju skaičiaus priklausomybę nuo substrato taršaly ir azoto trąšu koncentracijos poveikio; tuo pagrindu nustatyti šiu augalu tinkamumą fitoremediacijai. Nustatyta tolerantiškas augalas t.y. fitoremediatorius Tagetes patula L, prisitaikęs augti užteršto ir azotu tręšiamo substrato sąlygomis bei tinkamas auginimui analogiškomis edafinemis sąlygomis. Netolerantiškas augalas, t.y. fitoindikatorius, yra Trifolium repens L. - Fabaceae Lindl. šeimos daugiametis, žolinis augalas, kurio rizosferoje yra maksimalus grybų ir bakterijų koloniju skaičius, esant maksimalioms azoto trąšų ir teršalu koncentracijoms. Šie bakteriologiniai ir mikologiniai procesai bei azoto perteklius neigiamai veikia Trifolium repens $L$. antžeminès ir požeminės daliu augimą.

Raktiniai žodžiai: fitoremediacija, žoliniai augalai, rizosfera, mikroorganizmai, substrato tarša, azoto trąšos. 